Vol. 7 (1998): 357-366.

\title{
Barley fibre and wet distillers' solubles in the diet of growing cattle
}

Tarja Root

Department of Animal Science, PO Box 28, FIN-00014 University of Helsinki,

Finland, e-mail: tarja.root@helsinki.fi

Pekka Huhtanen

Department of Animal Science, University of Helsinki, Finland. Current address: Agricultural Research Centre of Finland, Animal Production Research, FIN-31600 Jokioinen, Finland

\begin{abstract}
Twenty-eight bulls were used in a $3 \times 2$ factorial design to study the effects of two by-products from the integrated starch-ethanol process, barley fibre and distillers' solubles, as supplements for grass silage. The animals were divided into five blocks and slaughtered when the average live weight (LW) of each block reached $500 \mathrm{~kg}$. The three energy supplements were barley (B), a mixture (1:1 on a dry matter (DM) basis) of barley and barley fibre (BF), and barley fibre (F), fed without (DS-) or with (DS+) wet distillers' solubles ( $200 \mathrm{~g} \mathrm{~kg}^{-1}$ concentrate on DM basis). Concentrates were given at the rate of $95 \mathrm{~g} \mathrm{DM} \mathrm{kg}^{-1} \mathrm{LW}^{0.6}$.

Including barley fibre in the diet did not affect feed intake, but distillers' solubles tended to increase both silage and total DM intakes as well as amino acids absorbed in the intestine and energy intake. The protein balance in the rumen increased with the inclusion of barley fibre $(\mathrm{P}<0.001)$ and distillers' solubles in the diet $(\mathrm{P}<0.01)$. Even though barley fibre had lower energy content than barley, it did not affect metabolizable energy (ME) intake markedly.

The average daily LW gain of all groups was high, and it was not significantly different for the various supplements. However, towards the end of the experiment the LW gain of bulls fed with barley fibre tended to decrease compared to barley. Feed conversion rates in terms of $\mathrm{kg}$ DM and MJ $\mathrm{ME} \mathrm{kg}{ }^{-1} \mathrm{LW}$ gain and the carcass weight or quality were not significantly affected by the treatments.
\end{abstract}

Key words: barley, bulls, by-products, grass silage, supplementation

\section{Introduction}

In Finland the usual concentrate supplement to grass silage is barley and the most common pro- tein feed is rapeseed meal in the feeding of both dairy and beef cattle. The growth rate of bulls given $2-4 \mathrm{~kg}$ barley daily and good quality silage ad libitum has resulted in high live weight (LW) gains which are difficult to improve with 
Root, T. \& Huhtanen, P. Barley fibre and wet distillers' solubles in the diet of growing cattle

protein supplementation or by other energy supplements (Kay and Harland 1988, Aronen and Vanhatalo 1992). However, it is necessary to study alternative energy and protein sources for environmental and economical reasons.

The integrated starch-ethanol process gives many by-products that are suitable for animal feeding (Näsi 1988), of which barley fibre (BF) and wet distillers' solubles (WDS) are most commonly used. Barley fibre consists of the cell-wall fraction of endosperm with $550 \mathrm{~g}$ neutral detergent fibre (NDF) and $90 \mathrm{~g}$ starch per kg dry matter (DM). Barley fibre has not been studied widely in the feeding of growing cattle, but in one study (Huhtanen et al. 1989) replacing barley with barley fibre decreased the daily gain of growing bulls by ca. $70 \mathrm{~g} \mathrm{~d}^{-1}$. The calculated energy value of barley fibre was about $90 \%$ that of barley. Results with dairy cows showed that there was either no difference in the milk yield of cows given barley or barley fibre (Huhtanen et al. 1988 ) or milk yield was higher with barley fibre diets (Ala-Seppälä et al. 1988). In a study with cannulated animals barley fibre increased the proportion of propionate in rumen volatile fatty acids (VFA) and duodenal non-ammonia nitrogen (NAN) flow compared with barley (Huhtanen 1992).

Another by-product from integrated starchethanol production is wet distillers' solubles, the value of which, as a protein source for growing cattle, has not been studied. Compared with barley and barley fibre, the crude protein content in distillers' solubles is high, approximately $300 \mathrm{~g}$ $(\mathrm{kg} \mathrm{DM})^{-1}$. In addition, having a high lactic acid content $\left(150 \mathrm{~g}(\mathrm{~kg} \mathrm{DM})^{-1}\right)$, wet distillers' solubles tend to increase the proportion of propionic acid in the rumen VFA (Huhtanen 1992), which can have positive effects in the feeding of growing cattle. When replacing barley, wet distillers' solubles have been shown to increase milk yield, mainly due to increased feed intake and metabolizable energy (ME) supply when wet distillers' solubles were included in the diet (Huhtanen and Miettinen 1992). Since the demand for both glucose and protein is higher for milk production than for growth, dairy cows did benefit from barley fibre and WDS because they balanced nutrient supply and increased NAN flow in the duodenum.

The purpose of this trial was to study the effects of replacing barley with barley fibre, with or without distillers' solubles, on the performance of bulls given grass silage ad libitum. Wet distillers' solubles replaced part of the barley and/or barley fibre.

\section{Material and methods}

\section{Animals, diets and experimental procedures}

The animals used in the trial were 15 Friesian, 8 Ayrshire and 5 Hereford bulls with a mean initial live weight of 205 (SE 4.6) kg. They were divided into five blocks by breed and LW, and randomly assigned to treatments within each block. The Hereford block included one Friesian animal, and each of the two Friesian blocks had one Ayrshire animal. The bulls were housed in a tie-up barn and individually fed twice a day. The animals were weighed on two consecutive days at the beginning and the end of the experiment, and at 28-day interval during the trial. LW gains were calculated for each animal both by the difference method and with a second-degree polynomial regression of $\mathrm{LW}$ on time.

A $3 \times 2$ factorial design was used to study the effects of by-products from the integrated starch-ethanol process (Näsi 1988) as supplements to grass silage. The three energy supplements were barley (B), a mixture (1:1 on dry matter (DM) basis) of barley and barley fibre (BF), and barley fibre (F), fed without (DS-) or with (DS+) wet distillers' solubles (200 $\mathrm{g} \mathrm{kg}^{-1}$ concentrate on DM basis). Concentrates were given at a rate of $95 \mathrm{~g} \mathrm{DM} \mathrm{kg}^{-1} \mathrm{LW}^{0.6}$ based on the LW of the animals at the beginning of each experimental period ( $28 \mathrm{~d}$ ) to maintain a constant forage to concentrate ratio throughout the experiment. The daily ration also included $150 \mathrm{~g}$ of a mineral mixture. To improve palatability, $10-20 \%$ distillers' solubles was added to the 


\section{AGRICULTURAL AND FOOD SCIENCE IN FINLAND}

Vol. 7 (1998): 357-366.

barley fibre during the production process, and it was fed to the animals in pelleted form. Wet distillers' solubles contained sodium benzoate (E211) $1.5 \mathrm{~g} \mathrm{~kg}^{-1}$ as a preservative, and it was delivered to the farm every second week (300 1). To reduce the degradability of protein in the rumen, wet distillers' solubles were treated with a solution (Graintona) containing formalin $(410 \mathrm{~g}$ $\left.\mathrm{kg}^{-1}\right)$, short-chain fatty acids $\left(430 \mathrm{~g} \mathrm{~kg}^{-1}\right)$, lignone sulphonate $\left(75 \mathrm{~g} \mathrm{~kg}^{-1}\right)$ and urea+utropine stabilizer $\left(75 \mathrm{~g} \mathrm{~kg}^{-1}\right)$ (European Patent Office 1982). The application rate of Graintona was $3.71 \mathrm{tn}^{-1}$. Barley, barley fibre and distillers' solubles were weighed separately and mixed before feeding. Grass silage (GS) was prepared from the primary growth of a timothy-meadow fescue sward, treated with a formic acid-based additive $(800 \mathrm{~g}$ formic acid $\mathrm{kg}^{-1}, 20 \mathrm{~g}$ orthophosphoric acid $\mathrm{kg}^{-1}$ ) at the rate of $4 \mathrm{lt}^{-1}$ and ensiled in bunker silos. Silage was fed ad libitum.

When the average LW of cattle in each block of animals reached $500 \mathrm{~kg}$, they were slaughtered, and thus the time in the trial ranged between 168 to 280 days. Dressing percentages were calculated as a proportion of hot carcass weight to final live weight. The carcasses were visually graded for conformation and fatness using the carcass classification scheme of Finnish commercial slaughter houses.

\section{Sampling and analytical methods}

Silage, barley and barley fibre were sampled weekly and analyzed for DM. Distillers' solubles was sampled once every fortnight. Silage samples were pooled over four weeks and concentrates over eight weeks for analyses.

The DM content of feeds was determined by oven drying at $105^{\circ} \mathrm{C}$ for $24 \mathrm{~h}$. Feed analyses were made according to standard procedures (AOAC 1984). The amount of ether extract was determined after acid $(\mathrm{HCl})$ hydrolysis. Silage DM content was corrected for volatile losses of lactic acid, VFA and ammonia as described by Porter et al. (1984). Neutral detergent fibre (NDF), acid detergent fibre (ADF) and acid detergent lignin (ADL) were analysed according to Goering and Van Soest (1970) with the modification by Robertson and Van Soest (1977) for barley. Ammonia N (McCullough 1967), lactic acid (Barker and Summerson 1941), sugars (Nelson 1944) and VFA (Huida 1973) were analysed and $\mathrm{pH}$ measured from fresh silage and distillers' solubles samples.

\section{Calculation of results and statistical analyses}

Energy and protein requirements were calculated for each animal for every $28 \mathrm{~d}$ experimental period. Requirements for the ME (Finnish feed unit (FFU), which is based on metabolizable energy), was calculated according to ARC (1980) (Tuori et al. 1996). Protein requirements were calculated according to the Nordic protein evaluation system modified for Finnish conditions (Tuori et al. 1996). The feeding values for the experimental feeds were calculated according to MAFF (1975) and Tuori et al. (1996). The carcass gain of the animals was calculated assuming that the carcass weight at the beginning of the experiment was LW $x 0.50$.

The model for analysing data was $\mathrm{y}_{\mathrm{ijkl}}=\mu+$ $\mathrm{E}_{\mathrm{i}}+\mathrm{P}_{\mathrm{j}}+(\mathrm{EP})_{\mathrm{ij}}+\mathrm{B}_{\mathrm{k}}+\mathrm{e}_{\mathrm{ijk} \text {, }}$, where E, P and B are the effects of energy supplement, wet distillers' solubles and block. The effect of the energy supplement was further partitioned into linear and quadratic effects of the replacement of barley with barley fibre by using polynomial contrasts (Snedecor and Cochran 1989). The interactions were not statistically significant $(\mathrm{P}>0.10$ for all parameters), and therefore the results are presented only for the main effects of the energy and protein supplements.

\section{Results}

The mean chemical compositon and estimated feeding values of the feeds are presented in Table 1 . The silage used was of good quality in 
Root, T. \& Huhtanen, P. Barley fibre and wet distillers' solubles in the diet of growing cattle

Table 1. Chemical composition of the feeds ( $\mathrm{g} \mathrm{kg}^{-1}$ dry matter) and estimated feed values.

\begin{tabular}{lcccc}
\hline & $\begin{array}{c}\text { Grass } \\
\text { silage }\end{array}$ & Barley & $\begin{array}{l}\text { Barley } \\
\text { fibre }\end{array}$ & $\begin{array}{l}\text { Distillers' } \\
\text { solubles }\end{array}$ \\
\hline Dry matter $\left(\mathrm{g} \mathrm{kg}^{-1}\right)$ & 282 & 864 & 907 & 330 \\
In dry matter $\left(\mathrm{g} \mathrm{kg}^{-1}\right)$ & & & & \\
$\quad$ Ash & 88 & 26 & 37 & 127 \\
Crude protein & 125 & 113 & 170 & 273 \\
Ether extract & 36 & 33 & 70 & 68 \\
Crude fibre & 279 & 52 & 167 & 13 \\
N-free extract & 472 & 776 & 556 & 518 \\
NDF & 508 & 214 & 632 & - \\
ADF & 290 & 55 & 198 & - \\
ADL & 22 & 6 & 27 & - \\
Feed values & & & & \\
ME, MJ (kg DM)-1 & 10.5 & 13.8 & 11.7 & 12.4 \\
AAT, g (kg DM)-1 & 79 & 103 & 107 & 115 \\
PBV, g (kg DM) & -1 & -56 & 1 & 92 \\
\hline
\end{tabular}

$\mathrm{NDF}=$ neutral detergent fibre, $\mathrm{ADL}=$ acid detergent lignin

$\mathrm{AAT}=$ amino acids absorbed in the intestine, $\mathrm{PBV}=$ protein balance in the rumen

In silage: $\mathrm{pH} 4.08$; in DM ( $\left.\mathrm{g} \mathrm{kg}^{-1}\right)$ : lactic acid 44, acetic acid 17 , butyric acid 0.3 , water soluble carbohy-

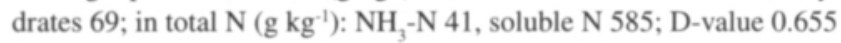

In distillers' solubles: in DM ( $\left.\mathrm{g} \mathrm{kg}^{-1}\right)$ : lactic acid 151

terms of both fermentation characteristics (41 g $\mathrm{NH}_{3}-\mathrm{N} \mathrm{kg}^{-1}$ total $\left.\mathrm{N}\right)$ and D-value $(0.655$, based on in vitro digestibility (Tilley and Terry 1963)). Barley fibre and wet distillers' solubles contained almost twice as much fat as barley because the fat from barley does not separate during the production process but accumulates into the byproducts. The calculated energy value of barley was $18 \%$ higher than that of barley fibre, but barley fibre contained slightly more AAT (amino acids absorbed in the intestine) (107 vs. $103 \mathrm{~g}$ $\left(\mathrm{kg} \mathrm{DM}^{-1}\right.$ ) and its PBV (protein balance in the

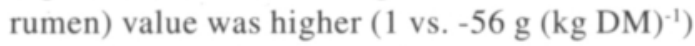
compared with barley. Distillers' solubles had a

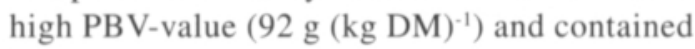
$151 \mathrm{~g}$ lactic acid $(\mathrm{kg} \mathrm{DM})^{-1}$.

The inclusion of distillers' solubles to the diet had a tendency to increase silage and total DM as well as AAT and energy intake (Table 2). However, these effects were not statistically significant. The palatability of barley fibre was good, since the average concentrate intake was not affected by the energy supplement. The pro- tein balance in the rumen (PBV) increased with barley fibre $(\mathrm{P}<0.001)$ and distillers' solubles in the diet $(\mathrm{P}<0.01)$. Even though barley fibre had lower energy values than barley, this fact did not affect the ME intake markedly because of slightly higher silage DM intake (Table 2).

The average daily live weight gain of all groups was high, and was not significantly affected by any supplement. The feed-conversion rates in terms of $\mathrm{kg} \mathrm{DM}$ and MJ ME per $\mathrm{kg} \mathrm{LW}$ gain were not significantly affected. There were no significant differences in carcass weight or quality between the treatments (Table 3).

The growth rates of bulls given $\mathrm{BF}$ and $\mathrm{F}$ diets were higher than with the $\mathrm{B}$ diet in the beginning of the trial ( $\mathrm{LW}<350 \mathrm{~kg}$ ) but the difference was not statistically significant. Inclusion of barley fibre in the diet decreased the daily gain towards the end of the experiment $(\mathrm{P}<0.10)(\mathrm{Ta}-$ ble 4). Inclusion of distillers' solubles in the diet did not affect the growth rate. The dry matter intake was not affected by the energy supplement throughout the trial, but distillers' solubles in- 
Vol. 7 (1998): 357-366.

Table 2. Feed intake ( $\mathrm{kg}$ dry matter $\left.\mathrm{d}^{-1}\right)$ and nutrient consumption.

\begin{tabular}{|c|c|c|c|c|c|c|c|c|}
\hline & \multicolumn{2}{|c|}{ Energy supplement } & \multicolumn{3}{|c|}{ DS } & \multirow{2}{*}{$\begin{array}{l}\mathrm{SEM}^{1} \\
18 \mathrm{df}\end{array}$} & \multicolumn{2}{|c|}{ Statistical significance ${ }^{2}$} \\
\hline & B & $\mathrm{BF}$ & $\mathrm{F}$ & - & + & & energy linear & DS \\
\hline \multicolumn{9}{|c|}{ Intake, $\left(\mathrm{kg}\right.$ dry matter $\left.\mathrm{d}^{-1}\right)$} \\
\hline Grass silage & 4.54 & 4.67 & 4.82 & 4.53 & 4.81 & 0.173 & & \\
\hline Concentrates & 2.97 & 3.07 & 3.00 & 2.93 & 3.09 & 0.127 & & \\
\hline Total DM intake & 7.51 & 7.74 & 7.82 & 7.46 & 7.90 & 0.249 & & \\
\hline DM intake $\mathrm{g} \mathrm{kg}^{-1} \mathrm{~W}^{0.75}$ & 94.0 & 97.5 & 97.7 & 94.2 & 98.6 & 1.91 & & \\
\hline $\mathrm{ME}, \mathrm{MJ} \mathrm{d}^{-1}$ & 86.5 & 86.2 & 83.7 & 83.3 & 87.7 & 2.76 & & \\
\hline AAT, $\mathrm{g} \mathrm{d}^{-1}$ & 661 & 688 & 695 & 659 & 703 & 22.0 & & \\
\hline PBV, $\mathrm{g} \mathrm{d}^{-1}$ & -156 & -93 & -35 & -124 & -65 & 13.2 & *** & $* *$ \\
\hline
\end{tabular}

' SEM of the energy supplements, SEM of DS is $0.816 \times$ SEM of energy supplements

${ }^{2}$ The effect of energy supplement is linear and distillers' solubles quadratic

Significance: o $(\mathrm{P}<0.10),{ }^{*}(\mathrm{P}<0.05),{ }^{* *}(\mathrm{P}<0.01),{ }^{* * *}(\mathrm{P}<0.001)$

$\mathrm{AAT}=$ amino acids absorbed in the intestine, $\mathrm{PBV}=$ protein balance in the rumen

Table 3. Animal production data.

\begin{tabular}{|c|c|c|c|c|c|c|c|c|}
\hline & \multicolumn{2}{|c|}{ Energy supplement } & \multicolumn{3}{|c|}{ DS } & \multirow{2}{*}{$\begin{array}{l}\mathrm{SEM}^{2} \\
18 \mathrm{df}\end{array}$} & \multicolumn{2}{|c|}{ Statistical significance } \\
\hline & B & $\mathrm{BF}$ & $\mathrm{F}$ & - & + & & energy linear & DS \\
\hline Initial live weight, $\mathrm{kg}$ & 205 & 203 & 208 & 203 & 208 & 7.9 & & \\
\hline Final live weight, kg & 505 & 500 & 505 & 498 & 508 & 12.9 & & \\
\hline Live weight gain, $\mathrm{g} \mathrm{d}^{-1} 1$ & 1354 & 1324 & 1327 & 1325 & 1345 & 48 & & \\
\hline \multicolumn{9}{|l|}{ Feed conversion } \\
\hline Kg DM (kg LW gain $)^{-1}$ & $\begin{array}{l}1 \\
1\end{array}$ & 5.85 & 5.95 & 5.65 & 5.95 & 0.181 & & \\
\hline MJ ME (kg LW gain $)^{-1}$ & 64.3 & 65.2 & 63.5 & 62.9 & 65.7 & 1.96 & & \\
\hline AAT g (kg LW gain $)^{-1}$ & 492 & 520 & 528 & 499 & 528 & 15.5 & & \\
\hline Carcass weight, $\mathrm{kg}$ & 266 & 259 & 258 & 260 & 262 & 6.5 & & \\
\hline Dressing -\% & 52.9 & 51.9 & 51.5 & 52.3 & 51.9 & 0.42 & o & \\
\hline Carcass gain, $\mathrm{g} \mathrm{d}^{-1}$ & 741 & 704 & 694 & 712 & 714 & 25.8 & & \\
\hline Quality grade ${ }^{3}$ & 13.2 & 12.9 & 12.6 & 13.0 & 12.8 & 0.18 & & \\
\hline Fatness grade ${ }^{4}$ & 7.3 & 7.2 & 7.1 & 7.2 & 7.2 & 0.17 & & \\
\hline
\end{tabular}

${ }^{1}$ Calculated by regression

${ }^{2}$ The effect of energy supplement is linear and distillers' solubles quadratic

Significance: o $(\mathrm{P}<0.10),{ }^{*}(\mathrm{P}<0.05),{ }^{* *}(\mathrm{P}<0.01),{ }^{* * *}(\mathrm{P}<0.001)$

${ }^{3} 15=$ highest quality, $10=$ lowest quality

${ }^{4} 6=$ no fat, $10=$ very fatty

LW = live weight, $\mathrm{AAT}=$ amino acids absorbed in the intestine

creased total DM intake during the latter period $(\mathrm{P}<0.10)$. Feed conversion efficiency $(\mathrm{kg} \mathrm{DM}(\mathrm{kg}$ LW gain $)^{-1}$ ) was impared linearly in the second stage of the growing period with increasing amounts of barley fibre in the diet $(\mathrm{P}<0.05)$.

Calculated energy requirement was higher than energy intake for all treatments but the intake to requirement ratio was not affected by treatments (Table 5). The protein (AAT) intake of the bulls was greater than the requirement during the whole trial especially with diets containing distillers' solubles $(\mathrm{P}<0.05)$. 
Root, T. \& Huhtanen, P. Barley fibre and wet distillers' solubles in the diet of growing cattle

Table 4. Daily live weight gains and dry matter intakes of bulls up to (stage 1) and above (stage 2) $350 \mathrm{~kg}$ live weight.

\begin{tabular}{|c|c|c|c|c|c|c|c|c|}
\hline & \multicolumn{2}{|c|}{ Energy supplement } & \multirow[b]{2}{*}{$\mathrm{F}$} & DS & \multirow[b]{2}{*}{+} & \multirow{2}{*}{$\begin{array}{l}\text { SEM }^{1} \\
18 \mathrm{df}\end{array}$} & \multicolumn{2}{|c|}{ Statistical significance } \\
\hline & B & $\mathrm{BF}$ & & - & & & energy linear & DS \\
\hline \multicolumn{9}{|c|}{ Live weight gain, $\mathrm{g} \mathrm{d}^{-1}$} \\
\hline stage 1 & 1288 & 1345 & 1378 & 1329 & 1345 & 44.8 & & \\
\hline stage 2 & 1420 & 1289 & 1254 & 1308 & 1334 & 64.9 & & o \\
\hline \multicolumn{9}{|c|}{ Silage intake, $\mathrm{kg} \mathrm{DM} \mathrm{d}^{-1}$} \\
\hline stage 1 & 4.02 & 4.29 & 4.21 & 4.07 & 4.27 & 0.175 & & \\
\hline stage 2 & 5.09 & 5.07 & 5.45 & 5.02 & 5.39 & 0.195 & & \\
\hline \multicolumn{9}{|c|}{ Concentrate intake, $\mathrm{kg} \mathrm{DM} \mathrm{d}^{-1}$} \\
\hline stage 1 & 2.58 & 2.70 & 2.72 & 2.65 & 2.69 & 0.081 & & \\
\hline stage 2 & 3.38 & 3.48 & 3.30 & 3.24 & 3.54 & 0.191 & & \\
\hline \multicolumn{9}{|c|}{ Total intake, $\mathrm{kg} \mathrm{DM} \mathrm{d}^{-1}$} \\
\hline stage 1 & 6.59 & 6.99 & 6.93 & 6.72 & 6.96 & 0.229 & & \\
\hline stage 2 & 8.47 & 8.55 & 8.76 & 8.26 & 8.93 & 0.307 & & o \\
\hline \multicolumn{9}{|c|}{ Feed conversion, $\mathrm{kg}$ DM (kg LW gain) ${ }^{-1}$} \\
\hline stage 1 & 5.14 & 5.22 & 5.06 & 5.08 & 5.20 & 0.209 & & \\
\hline stage 2 & 6.07 & 6.73 & 7.30 & 6.50 & 6.89 & 0.296 & $*$ & \\
\hline
\end{tabular}

'The effect of energy supplement is linear and distillers' solubles quadratic

Significance: o $(\mathrm{P}<0.10),{ }^{*}(\mathrm{P}<0.05),{ }^{* *}(\mathrm{P}<0.01),{ }^{* * *}(\mathrm{P}<0.001)$

$\mathrm{B}=$ barley, $\mathrm{BF}=$ barley + barley fibre $(1: 1), \mathrm{F}=$ barley fibre

Table 5 . The average daily energy and protein requirement of the bulls, and the intake/requirement ratio.

\begin{tabular}{|c|c|c|c|c|c|c|c|c|}
\hline & \multicolumn{2}{|c|}{ Energy supplement } & \multicolumn{3}{|c|}{ DS } & \multirow{2}{*}{$\begin{array}{l}\text { SEM }^{1} \\
18 \mathrm{df}\end{array}$} & \multicolumn{2}{|c|}{ Statistical significance } \\
\hline & B & BF & $\mathrm{F}$ & - & + & & energy linear & DS \\
\hline ME requirement, $\mathrm{MJ} \mathrm{d}^{-1}$ & 94.6 & 91.3 & 90.0 & 90.6 & 93.4 & 4.18 & & \\
\hline AAT requirement, $\mathrm{g} \mathrm{d}^{-1}$ & 601 & 600 & 603 & 598 & 605 & 10.7 & & \\
\hline \multicolumn{9}{|l|}{ Intake/requirement } \\
\hline ME & 0.920 .95 & 0.93 & 0.92 & 0.95 & 0.023 & & & \\
\hline AAT & 1.10 & 1.14 & 1.15 & 1.10 & 1.16 & 0.022 & & $*$ \\
\hline
\end{tabular}

' The effect of energy supplement is linear and distillers' solubles quadratic

Significance: o $(\mathrm{P}<0.10),{ }^{*}(\mathrm{P}<0.05),{ }^{* *}(\mathrm{P}<0.01),{ }^{* * *}(\mathrm{P}<0.001)$

$\mathrm{B}=$ barley, $\mathrm{BF}=$ barley + barley fibre $(1: 1), \mathrm{F}=$ barley fibresee table

$\mathrm{ME}=$ metabolizable energy, $\mathrm{AAT}=$ amino acids absorbed in the intestine

\section{Discussion}

\section{The effect of barley fibre}

In agreement with previous results obtained from replacing barley by barley fibre (Huhtanen et al. 1989) and sugar beet pulp (Jaakkola and Huhtanen 1990) in the feeding of growing cattle, the average intake of DM was not affected by bar- ley fibre in the present trial. In contrast, replacing starch by fibrous concentrates has been shown to increase feed intake in cows, when the intake of concentrates was high (Thomas et al. 1986). This is mainly due to improved rumen environment and cellulolysis leading to better digestibility of the diet with fibrous concentrates. Huhtanen et al. (1995) found that replacing starch with fibre in the diets of dairy cows had no effect on apparent digestibility of organic 
Vol. 7 (1998): 357-366.

matter but tended to increase the digestibility of neutral detergent fibre. However, the results with barley fibre in the feeding of cows showed lower digestibility of organic matter as well as fibre fractions compared to barley (Huhtanen et al. 1988, Huhtanen 1992).

The average daily gain of the animals was not affected by including barley fibre in the diet in the present trial. In the earlier study (Huhtanen et al. 1989), replacing barley with barley fibre decreased the daily gain of growing bulls by ca. $70 \mathrm{~g} \mathrm{~d}^{-1}$, but the barley fibre used then had lower energy and protein contents than that used in the present experiment. However, the pattern of growth of animals fed with barley fibre was different in these two experiments, the bulls growing faster in the beginning than the end of the present experiment. There were no such variation in the composition of BF during the experiment, which could explain the different growth pattern. Similar growth patterns to those observed in the present study with barley and BF were reported earlier by Huhtanen et al. (1989) and Jaakkola et al. (1990) in cattle fed either without or with supplementary protein. In these studies the animals given no protein supplements compensated for the slower LW gain in the beginning of the experiment by a faster LW gain in the end of the experiment, which may indicate that in the beginning the animals fed barley alone were more deficient in protein supply than those fed BF. Increased duodenal NAN flow (Huhtanen 1992) and milk protein yield (Ala-Seppälä et al. 1988) indicate a better protein value of $\mathrm{BF}$ compared with barley, which could support the faster LW gain in the beginning of the experiment.

According to the results of the present trial the value of barley fibre in the feeding of growing cattle was equal to that which would be expected from the values presented in the feed tables (Tuori et al. 1996). Huhtanen et al. (1989) reported that the relative value of BF was 0.90 of that of barley, ie. higher than could be expected from tabulated values. In the present experiment the estimated utilization of ME above maintenance $\left(\mathrm{k}_{\mathrm{f}}\right)$ increased with $\mathrm{BF}$ in the diet and was the opposite that could predicate ARC
(1980) equations. According to ARC the utilization of ME for fattening decreased with metabolizability of the diet (ME/gross energy) which was the case with increasing BF in the present trial. Thus the large proportion of digestible NDF in ME does not seem to result in low $k_{f}$ values when digestible NDF is derived from concentrates. In agreement with the results obtained from using barley fibre are the findings by Jaakkola and Huhtanen (1990), who fed sugar beet pulp to growing cattle.

Carcass weight or quality were not affected either by the energy supplement or wet distillers' solubles. The dressing percentage tended to be lower for barley fibre than barley diets, which may be due to differencies in rumen fill. Compared to the bulls fed barley fibre the animals fed barley may have stopped eating in smaller rumen fill for metabolic reasons, mainly the feedback mechanism of the increased amount of rumen fermentation end products, leading to lighter weight of the rumen contents with barley. Aronen et al. (1994) studied the filling effect of roughages with growing cattle and found that the digestive tract of animals fed straw and hay was heavier than with silage. With fibrous concentrates, however, the effect on dressing percentage has not been very clear (Huhtanen et al. 1989, Jaakkola and Huhtanen 1990).

\section{The effect of wet distillers' solubles}

Protein supplements can increase silage and total DM intake of animals, and due to this effect in the present trial the inclusion of distillers' solubles in the diet of growing cattle reduced the gap between ME requirement and supply especially at the end of the growing period. However, this did not improve the growth rate. The effects of wet distillers' solubles in the feeding of dairy cows on DM intake have been both positive (Huhtanen and Miettinen 1992) and neutral (Ala-Seppälä et al. 1988). Huhtanen et al. (1995) found that the feed intake of dairy cows was higher when wet distillers' solubles were fed with starchy concentrate but not when it was fed with fibrous concentrate. 


\section{AGRICULTURAL AND FOOD SCIENCE IN FINLAND}

Root, T. \& Huhtanen, P. Barley fibre and wet distillers' solubles in the diet of growing cattle

Distillers' solubles had a high concentration of lactic acid $\left(151 \mathrm{~g}(\mathrm{~kg} \mathrm{DM})^{-1}\right)$, and feeding DS to cattle has been shown to increase the molar proportion of propionate in the rumen (Huhtanen 1992), because lactate is fermented to propionate (Chamberlain et al. 1983). Therefore the inclusion of distillers' solubles to the diet can increase the supply of nutrients in the way that it provides more amino acids, which are preserved for animal products instead of glucose production. Dairy cows have been shown to respond to increased energy and amino acid supply by higher milk and milk protein yield with wet distillers' solubles in the diet with starchy concentrates (Huhtanen and Miettinen 1992, Huhtanen et al. 1995). Untreated dried distillers' solubles (UDDS) have not affected milk production, but the treatment of DDS with formaldehyde reagent tended to increase the yield of both milk and milk constituents, when distillers' solubles replaced a part of the basal concentrate (Huhtanen et al. 1991). However, the requirements for glucose and amino acids of growing cattle is relatively much smaller than of dairy cows, and therefore an increased glucose supply can have a positive effect on growth only with diets producing large amounts of acetic acid and containing small amount of protein.

In the grass silage-based feeding of growing cattle, fish meal (Jaakkola et al. 1990) and rapeseed meal (Huhtanen et al. 1989, Aronen 1990) have been shown to increase growth rates early in life ( $<250 \mathrm{~kg} \mathrm{LW})$, but often this advantage is lost later in the growing period due to compensatory growth (Steen 1988). In the present experiment, unlike with other protein supplements WDS had no effect on the daily growth rate of the bulls at any stage of the trial. From this it can be concluded that WDS did not increase the amino acid supply. In addition, it has been reported that despite the increased $\mathrm{N}$ intake by the inclusion of distillers' solubles to the diet, the total N or NAN flow in the duodenum was not changed (Huhtanen 1992). The high rumen degradability of protein in untreated dried distillers' solubles is also the probable reason for the lack of production response in dairy cows (AlaSeppälä et al. 1988). Huhtanen et al. (1991) com- pared rapeseed meal (RSM) and distillers' solubles as protein supplements for dairy cows and found no differencies in milk production except higher protein yield with RSM.

The response in LW gain to protein supplements is greatest when the LW gain without protein supplementation is low, which may be the case with low quality silage (Steen 1988) or roughage (Aronen 1990), extensively fermented silage (Jaakkola et al. 1990) or a small amount of concentrates in the diet (Pike et al. 1988). The good quality silage and adequate amount of barley in the feeding of the bulls in the present experiment led to very high growth rates, and then also the microbial protein synthesis can be assumed to have been high, and therefore no positive effects could be expected from protein supplementation. The benefit from protein supplementation depends on the growth rate that is achieved with the basic feeding (Jaakkola 1992, Aronen 1992). The genetic growth capacity of bulls from dairy breeds may also have been a limiting factor, even if there had been an increase in nutrient supply.

\section{Conclusions}

The results of this experiment show that when fed with high quality silage, barley fibre is a good energy supplement for growing cattle. The feed value of barley fibre in relation to barley in terms of animal performance is close to its predicted feeding value, but since the price of grain is low at the moment, barley fibre should be very inexpensive to make its use profitable. Distillers' solubles did not have a significant effect on the LW gain or on feed conversion. The absence of response to distillers' solubles and the high LW gains in cattle given $3 \mathrm{~kg}$ of concentrate DM along with grass silage suggests that the protein requirements of bulls above $200 \mathrm{~kg}$ can be met without protein supplements, providing that the silage is of high quality.

Feeding of the by-products from integrated starch-ethanol production to dairy cows has giv- 


\section{AGRICULTURAL AND FOOD SCIENCE IN FINLAND}

Vol. 7 (1998): 357-366.

en better results than feeding them to growing cattle. Therefore it would be more beneficial to feed barley fibre and wet distillers' solubles to cows, if there is enough demand for these feedstuffs on dairy farms.

\section{References}

Ala-Seppălä, H., Huhtanen, P. \& Näsi, M. 1988. Silage intake and milk production in cows given barley or barley fibre with or without dried distillers solubles. Journal of Agricultural Science in Finland 60: 723733.

AOAC 1984. Official methods of analysis. Association of Official Analytical Chemists, Inc., Arlington, Virginia. $1141 \mathrm{p}$.

ARC 1980. The Nutrient Requirements of Ruminants. Commonwealth Agricultural Bureaux. Agricultural Research Council. London. $351 \mathrm{p}$.

Aronen, I. 1990. Barley protein and rapeseed meal as protein supplements for growing cattle. Acta Agriculturae Scandinavica 40: 297-307.

- 1992. Quality of supplementary feed protein for growing cattle. Dissertation. University of Helsinki, Department of Animal Science. $46 \mathrm{p}$.

- , Lampila, M. \& Hepola, H. 1994. Comparison of diets based on grass silage, hay or oat straw supplemented with four levels of concentrates in the feeding of growing Ayrshire bulls. Agricultural Science in Finland 3: 15-26.

- \& Vanhatalo, A. 1992. Heat-moisture treatment of rapeseed meal: Effect on digestibility of the diet, voluntary grass silage intake and growth rate of Ayrshire bulls. Acta Agriculturae Scandinavica 42: 157166.

Barker, S.B. \& Summerson, W.H. 1941. The colorimetric determination of lactic acid in biological material. Journal of Biological Chemistry 138: 535-554.

Chamberlain, D.G., Thomas, P.C. \& Anderson, F.I. 1983. Volatile fatty acid proportios and lactic acid metabolism in the rumen of sheep and cattle receiving silage diets. Journal of Agricultural Science, Cambridge 101: 47-58.

European Patent Office 1982. Additive composition for animal feedingstuff. European Patent Application No. 0043202.

Goering, H.R. \& Van Soest, P.J. 1970. Forage fiber analyses. Agriculture Handbook No. 379. United States Deptartment of Agriculture, Washington.

Huhtanen, P. 1988. The effects of barley, unmolassed sugar-beet pulp and molasses supplements on organic matter, nitrogen and fibre digestion in the rumen of cattle given a silage diet. Animal Feed Science and Technology 20: 259-278.

- 1992. The effects of barley vs. barley fibre with or without distiller's solubles on site and extent of nutrient digestion in cattle fed grass-silage-based diet. Animal Feed Science and Technology 36: 319-337.

- , Ala-Seppälă, H. \& Năsi, M. 1988. Response of silage intake and milk production to replacement of barley fibre derived from integrated starch-ethanol process. Journal of Agricultural Science in Finland 60: 711-721.

- , Jaakkola, S. \& Saarisalo, E. 1995. The effects of concentrate energy source on milk production of dairy cows given a grass silage-based diet. Animal Science 60: 31-40.

- Khalili, H. \& Năsi, M. 1991. A comparison of untreated and formaldehyde-treated barley distiller's solubles and rapeseed meal as protein supplements in dairy cows given grass silage ad libitum. Journal of Agricultural Science in Finland 63: 455-463.

- \& Miettinen, H. 1992. Milk production and concentrations of blood metabolites as influenced by the level of wet distiller's solubles in dairy cows receiving grass silage-based diet. Agricultural Science in Finland 1: 279-290.

- , Näsi, M. \& Khalili, H. 1989. By-products from integrated starch-ethanol production from barley in the diets og growing cattle. Journal of Agricultural Science in Finland 61: 451-462.

Huida, L. 1973. Quantitative determination of volatile fatty acids by gasliquid chromatography. Journal of the Scientific Agricultural Society of Finland 45: 483-488.

Jaakkola, S. 1992. Silage fermentation in relation to the feeding value with special reference to enzyme-treated grass silage. Dissertation. University of Helsinki, Department of Animal Science. 54 p.

- \& Huhtanen, P. 1990. Response to cellulase treatment of silage and replacement of barley by unmolassed sugar beet pulp in the diets of growing cattle. Acta Agriculturae Scandinavica 40: 415-426.

- Huhtanen, P. \& Vanhatalo, A. 1990. Fermentation quality of grass silage treated with enzymes of formic acid and nutritive value in growing cattle fed with or without fish meal. Acta Agriculturae Scandinavica 40: 403-414.

Kay, R.M. \& Harland, J.I. 1988. Fish-meal supplementation of sugar-beet feed or barley-based concentrates for finishing beef cattle fed grass silage diets. Animal Production 46: 525 (Absr.)

MAFF 1975. Energy allowancesand feeding systems for ruminants. Ministry of Agriculture, Food and Fisheries. London. Technical Bulletin 33. 79 p.

McCullough, H. 1967. The determination of ammonia in whole blood by direct calorimetric method. Clinica Chimica Acta 17: 297-304.

Năsi, M. 1988. Evaluation of barley feed fractions from integrated ethanol-starch production in diets of ruminants. Journal of Agricultural Science in Finland 60: 701-709.

Nelson, N. 1944. A photometric adaptation of Somogyi 
Root, T. \& Huhtanen, P. Barley fibre and wet distillers' solubles in the diet of growing cattle

method for determination of glucose.

Journal of Biological Chemistry 153: 375-380.

Pike, I.H., Smith, G. \& Miller, E.L. 1988. An evaluation of fish meal as a protein supplement for beef cattle. Proceedings of the VII World Conference in Animal Production. p. 427.

Porter, M.G., Patterson, D.C., Steen, R.W. \& Gordon, F.J. 1984. Determination of dry matter and gross energy of grass silage. In: Gordon, F.J. \& Unsworth, E.F. (eds.). Proceedings of the 7th Silage Conference, Queen's University, Belfast. p. 89-90.

Robertson, J.B. \& Van Soest, P.J. 1977. Dietary fiber estimation in concentrate feedstuffs. 69th meeting of American Society of Animal Science. p. 639.

Snedecor, G.W. \& Cochran, W.C. 1989. Statistical Methods. 8th edition. Iowa State Univ. Press. Ames.
$503 \mathrm{p}$.

Steen, R.W. 1988. The effect of additive treatment of grass silage and food additive avoparcin on the response of calves to supplementation of silage-based diets with fish meal. Animal Production 41: 293-300.

Thomas, C., Aston, K., Daley, S.R. \& Bass, J. 1986. Milk production from grass. 4 . The effect of the composition of the supplement. Animal Production 42: 315325.

Tilley, J.M.A. \& Terry, R.A. 1963. A two-stage technique for the in vitro digestion of forage crops. Journal of the British Grassland Society 18: 104-111.

Tuori, M., Kaustell, K., Valaja, J., Aimonen, E., Saarisalo, E. \& Huhtanen, P. 1996. Rehutaulukot ja ruokintasuositukset. (Feed tables and nutrient recommendations), Yliopistopaino Helsinki. 99 p. (in Finnish).

\title{
SELOSTUS
}

\section{Ohrarehu ja tärkkelysrankki kasvavien lihanautojen säilörehuun perustuvassa ruokinnassa}

\author{
Tarja Root ja Pekka Huhtanen \\ Helsingin yliopisto
}

Tärkkelys-etanolituotannon oheistuotteina saadaan useita märehtijöiden ruokintaan soveltuvia rehuja, joista tärkeimpiä ovat ohrarehu ja tiivistetty tärkkelysrankki. Tutkimuksen tavoitteena oli selvittää ohran korvaamista ohrarehulla joko ilman tiivistettyä tärkkelysrankkia tai sen kanssa kasvavien lihanautojen vapaaseen säilörehun syöntiin perustuvassa ruokinnassa. Kokeessa oli 28 sonnia, joiden alkupaino oli keskimäärin $205 \mathrm{~kg}$ ja elopaino teurastettaessa noin $500 \mathrm{~kg}$. Energiaväkirehuna kokeessa oli ohra, ohran ja ohrarehun seos (1:1) sekä ohrarehu. Tärkkelysrankkilisällä korvattiin kunkin energiaväkirehun kuiva-aineesta (ka) $200 \mathrm{~g} \mathrm{~kg}^{-1}$ tai ei. Väkirehua annettiin $95 \mathrm{~g} \mathrm{ka}$ (elopaino-kg) ${ }^{0.6}$.

Säilörehu oli käymislaadultaan ja sulavuudeltaan hyvälaatuista, mikä vaikutti sonnien suureen kuivaaineen syöntiin. Ohrarehu sisälsi runsaasti enemmän kuitua ja raakavalkuaista kuin ohra, jonka energiapitoisuus oli $18 \%$ suurempi kuin ohrarehun. Tärkkelysrankissa oli tyypillisesti paljon valkuaista ja maitohappoa.

Ohrarehu ja tärkkelysrankki lisäsivät sonnien säilörehun ja kokonaiskuiva-aineen syöntiä sekä ohutsuolesta imeytyvien aminohappojen saantia, mutta vain tärkkelysrankki lisäsi energian saantia varsinkin kasvatuskauden lopussa. Vaikka ohrarehu sisälsi vähemmän energiaa kuin ohra, ei se juurikaan vaikuttanut sonnien keskimääräiseen muuntokelpoisen energian saantiin, sillä säilörehun syönti lisääntyi. Kuitenkin kasvatuskauden loppupuoliskolla (elopaino yli $300 \mathrm{~kg}$ ) ohrarehua väkirehunaan saaneiden sonnien energian saannin ja tarpeen välillä oli suurin ero. Rehuannoksen pötsin valkuaistase parani sekä ohrarehun että tärkkelysrankin vaikutuksesta. Kaikkien ruokintaryhmien sonnien valkuaisen saanti (OIV) ylitti tarpeen koko kokeen ajan.

Sonnien keskimääräinen päiväkasvu oli erinomainen $\left(1330 \mathrm{~g} \mathrm{~d}^{-1}\right)$ eikä ruokintaryhmien välillä ollut eroa. Kun koeaika jaetaan kahteen osaan, kokeen alussa ohrarehua väkirehussaan saaneet sonnit kasvoivat nopeammin kuin ohraryhmä, mutta lopussa ohrarehuryhmien kasvu hidastui selvästi. Ohrarehun positiivinen vaikutus kasvatuksen alussa voi johtua sonnien lisääntyneestä aminohappojen saannista. Tärkkelysrankki ei parantanut sonnien kasvua merkitsevästi kokeen loppupuolella, vaikka syönti lisääntyi. Teurastuloksiin ei ohrarehulla tai tärkkelysrankilla ollut vaikutusta. 